Article

\title{
Crystal Structures and Antifungal Activities of Fluorine-Containing Thioureido Complexes with Nickel(II)
}

\author{
Chun Li ${ }^{1,2}$, Wen Yang ${ }^{2}$, Huanhuan Liu ${ }^{2}$, Mengying $\mathrm{Li}^{3}$, Weiqun Zhou ${ }^{2, *}$ and Juan Xie ${ }^{2}$ \\ 1 College of Pharmacy, Nantong Tichen Health School, Nantong 226007, China \\ 2 College of Chemistry, Chemical Engineering and Materials Science, Soochow University, \\ 199 Ren'ai Road, Suzhou 215123, China \\ 3 School of Biology \& Basic Medical Sciences, Soochow University, 199 Ren'ai Road, \\ Suzhou 215123, China \\ * Author to whom correspondence should be addressed; E-Mail: wqzhou@suda.edu.cn; \\ Tel.: +86-512-6588-4827.
}

Received: 13 November 2013; in revised form: 3 December 2013 / Accepted: 5 December 2013 / Published: 17 December 2013

\begin{abstract}
Ni}$ (II) complexes with $\mathrm{N}$-2-fluorobenzoylpiperidine-1-carbothioimidate (L2 ${ }^{-}$), $N$-4-fluorobenzoylpiperidine-1-carbothioimidate $\quad\left(\mathrm{L}^{-}{ }^{-}\right), \quad \mathrm{N}$-2-fluorobenzoylmorpholine1-carbothioimidate ( $5^{-}$) and N-4-fluorobenzoylmorpholine-1-carbothioimidate (L6) have been synthesized and characterized by elemental analysis, FTIR and ${ }^{1} \mathrm{H}-\mathrm{NMR}$. The crystal structures of three ligands (HL2, HL3 and HL6) and the corresponding Ni(II) complexes $\left(\left[\mathrm{Ni}(\mathrm{L} 2)_{2}\right],\left[\mathrm{Ni}(\mathrm{L} 3)_{2}\right]\right.$ and $\left.\left[\mathrm{Ni}(\mathrm{L} 6)_{2}\right]\right)$ have been determined by X-ray diffraction. The antifungal activities of the $\mathrm{Ni}(\mathrm{II})$ complexes together and the corresponding ligands against the fungi Botrytis cinerea, Trichoderma spp., Myrothecium and Verticillium spp. have been investigated. The experimental results showed that the ligands and their complexes have antifungal abilities. When the fluorine was substituted on the para-benzoyl moiety, the antifungal activity of the ligands was obviously increased. Moreover, the ligands were stronger than their complexes in inhibiting fungal activities. The antifungal ability of HL6 is especially strong, and similar to that of the commercial fungicide fluconazole.
\end{abstract}

Keywords: fluorobenzoyl thioureas; Ni(II) complexes; crystal structures; antifungal activity 


\section{Introduction}

As we know, pyridine, morpholine and thiourea exhibit broad biological activities, including antibacterial and antifungal effects [1-11]. 1,3-Dialkyl- or diarylthioureas present significant antifungal activity against the plant pathogens Pyricularia oryzae and Drechslera oryzae [12]. Acyl thioureas are well known for their superior pesticidal, fungicidal, antiviral and plant growth regulating activity [13]. Moreover, thioureas containing both carbonyl and thiocarbonyl groups are versatile ambidentate donor ligands for transition metal ions [14].

The introduction of fluorine at a strategic position of a molecule is a powerful and versatile tool for the development of organic molecules which have potential biological activities by changing the steric and electronic parameters [15-21]. The inclusion of fluorine into organic molecules can increase the lipophilicity and thus enhance the rate of cell penetration and transport of a drug to an active site [22]. Fluorinated thioureas constitute a novel class of potent influenza virus neuraminidase inhibitors.

The biological activities of metal complexes are different from those of either their ligands or the free metal ions. In many cases, upon coordination to metal ions, the bioactivity of these complexes increases, suggesting that complexation can be an interesting dose reduction strategy [23-28]. However, some $\mathrm{Co}(\mathrm{III})$ and $\mathrm{Ni}(\mathrm{II})$ complexes had the weaker antibacterial activities than the corresponding ligands [11,29]. The proximate experiments of our group on fluorobenzoylthioureas and their Co(III) complexes [29] have revealed the introducing a fluorine atom on para-benzoylthiourea increased the antibacterial activities, while when the fluorine atom was substituted on an ortho-benzoyl group, the antibacterial activity was weakened.

In this paper, we synthesized four complexes, [Ni(L2) $\left.)_{2}\right],\left[\mathrm{Ni}(\mathrm{L} 3)_{2}\right],\left[\mathrm{Ni}(\mathrm{L} 5)_{2}\right]$ and $\left[\mathrm{Ni}(\mathrm{L} 6)_{2}\right]$. The crystal structures of the three ligands (HL2, HL3, HL6) and the corresponding complexes were determined by X-ray diffraction. In consideration of the knwon good biological effects of nickel ion and its complexes [30,31], we were interested in exploring the effect of fluorine substitution and the coordination with $\mathrm{Ni}$ (II) on the antifungal activities.

\section{Results and Discussion}

\subsection{Structural Characteristic}

The molecule structures of the three ligands and the corresponding complexes with Ni(II) are shown in Figures 1-3, and their X-ray diffraction parameters are summarized in Table 1. Three ligands show trans-conformation between the $\mathrm{C}=\mathrm{S}$ and $\mathrm{C}=\mathrm{O}$. No significant differences appear in the bond lengths and bond angles of the three ligands (Table 3). The amidic $\mathrm{C}(1)-\mathrm{N}(1)$, thiomide $\mathrm{N}(2)-\mathrm{C}(8)$ and $\mathrm{N}(1)-\mathrm{C}(8)$ bonds are shorter than the $\mathrm{C}-\mathrm{N}$ single bond length of 1.472(5) $\mathrm{A}$. The partial double bond character of the structure is presumed as a result of the $p-\pi$ conjugation. The length of the bond $\mathrm{C}(8)-\mathrm{S}(1)$ lies between the values of $\mathrm{C}-\mathrm{S}$ single and double bonds. In the crystals of HL3, two molecules have some small conformational distinctions. 
Figure 1. Molecular structures of HL2 and [Ni(L2) 2 , with thermal ellipsoids drawn at $40 \%$ probability.

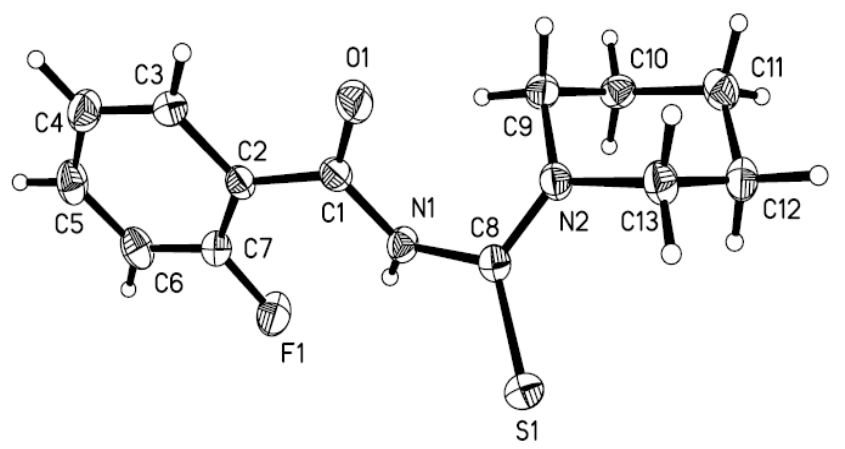

\section{HL2}

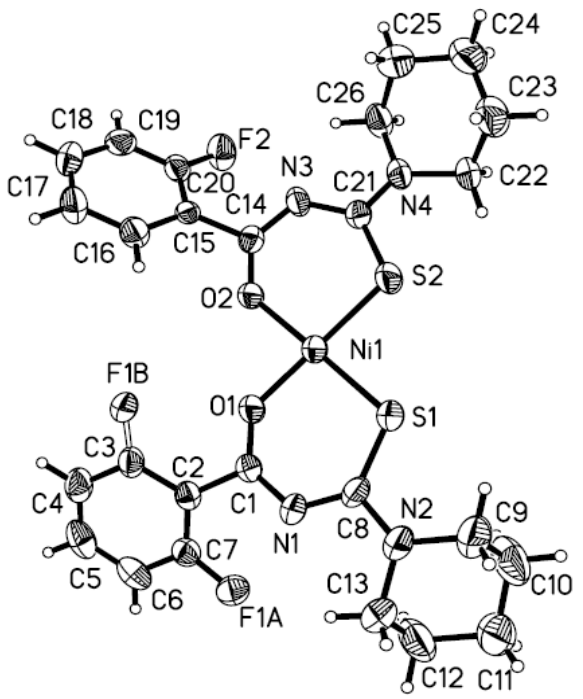

$\left[\mathrm{Ni}(\mathrm{L} 2)_{2}\right]$

Figure 2. Molecular structures of HL3 and [Ni(L3) 2$]$, with thermal ellipsoids drawn at $40 \%$ probability.
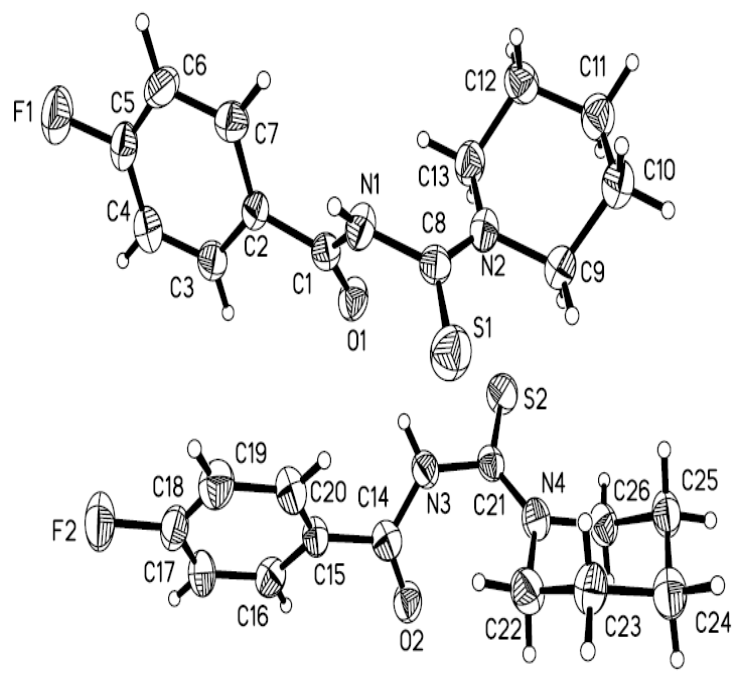

HL3

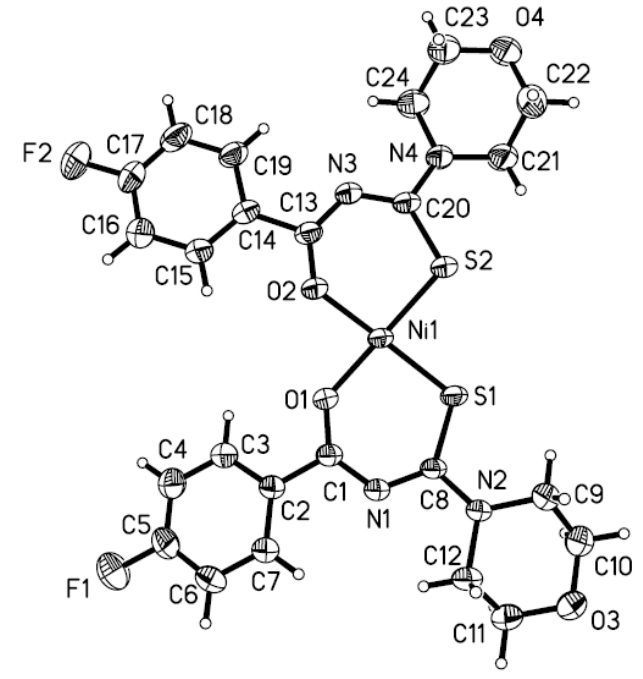

$\left[\mathrm{Ni}(\mathrm{L3})_{2}\right]$ 
Figure 3. Molecular structures of HL6 and $\left[\mathrm{Ni}(\mathrm{L} 6)_{2}\right]$ with thermal ellipsoids drawn at $40 \%$ probability.

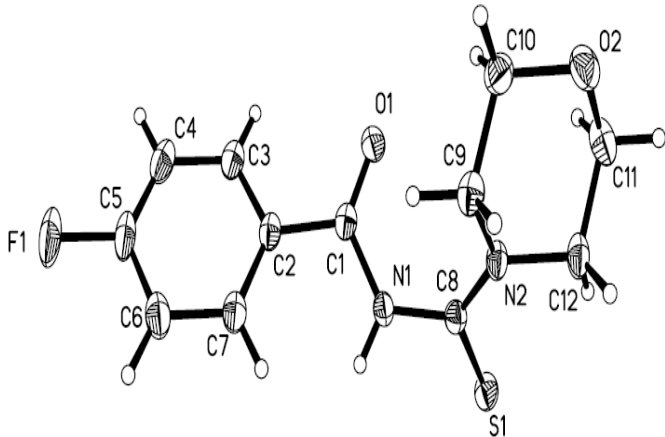

HL6

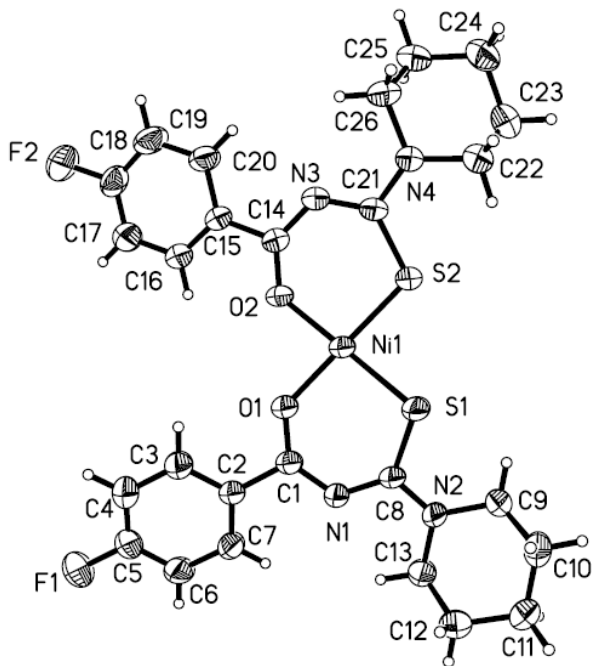

[Ni(L6) $\left.)_{2}\right]$

Table 1. Summary of X-ray diffraction data.

\begin{tabular}{|c|c|c|c|c|c|c|}
\hline Parameter & HL2 & {$\left[\mathrm{Ni}(\mathrm{L} 2)_{2}\right]$} & HL3 & {$\left[\mathrm{Ni}(\mathrm{L3})_{2}\right]$} & HL6 & {$\left[\mathrm{Ni}(\mathrm{L6})_{2}\right]$} \\
\hline Empirical formula & $\mathrm{C}_{13} \mathrm{H}_{15} \mathrm{FN}_{2} \mathrm{OS}$ & $\mathrm{C}_{26} \mathrm{H}_{28} \mathrm{~F}_{2} \mathrm{~N}_{4} \mathrm{NiO}_{2} \mathrm{~S}_{2}$ & $\mathrm{C}_{13} \mathrm{H}_{15} \mathrm{FN}_{2} \mathrm{OS}$ & $\mathrm{C}_{26} \mathrm{H}_{28} \mathrm{~F}_{2} \mathrm{~N}_{4} \mathrm{NiO}_{2} \mathrm{~S}_{2}$ & $\mathrm{C}_{12} \mathrm{H}_{13} \mathrm{FN}_{2} \mathrm{O}_{2} \mathrm{~S}$ & $\mathrm{C}_{24} \mathrm{H}_{24} \mathrm{~F}_{2} \mathrm{~N}_{4} \mathrm{NiO}_{4} \mathrm{~S}_{2}$ \\
\hline Formula weight & 266.33 & 589.35 & 266.33 & 589.35 & 268.3 & 593.3 \\
\hline Crystal system & Monoclinic & Orthorhombic & Triclinic & Triclinic & Monoclinic & Triclinic \\
\hline Space group & $P 21 / c$ & $P b c a$ & $P-1$ & $P-1$ & $C 2 / c$ & $P-1$ \\
\hline $\mathrm{a}(\AA)$ & $11.843(3)$ & $11.6111(17)$ & $8.3759(15)$ & $9.5530(16)$ & $21.214(6)$ & $9.3383(6)$ \\
\hline $\mathrm{b}(\AA)$ & $13.282(3)$ & $9.8778(17)$ & 11.191(2) & $11.890(2)$ & $9.7391(16)$ & $11.5273(9)$ \\
\hline c $(\AA)$ & $8.432(2)$ & $45.925(7)$ & $13.960(3)$ & $12.548(2)$ & $14.637(7)$ & $12.7230(8)$ \\
\hline$\alpha\left(^{\circ}\right)$ & 90 & 90 & $89.981(10)$ & $104.350(4)$ & 90 & $105.206(6)$ \\
\hline$\beta\left(^{\circ}\right)$ & $108.474(5)$ & 90 & $89.969(10)$ & $100.377(3)$ & $125.91(3)$ & $101.420(5)$ \\
\hline$\gamma\left({ }^{\circ}\right)$ & 90 & 90 & $79.699(9)$ & $97.110(4)$ & 90 & $96.112(6)$ \\
\hline $\mathrm{Z}$ & 4 & 8 & 4 & 2 & 8 & 2 \\
\hline Dcalc $\left(\mathrm{g} / \mathrm{cm}^{3}\right)$ & 1.406 & 1.486 & 1.374 & 1.464 & 1.455 & 1.543 \\
\hline $\begin{array}{c}\text { Radiation }(\mathrm{MoK} \alpha) \\
(\AA)\end{array}$ & 0.71075 & 0.7107 & 0.7107 & 0.7107 & 0.71075 & 0.71073 \\
\hline$\mu(\mathrm{Mo} \mathrm{K} \alpha)\left(\mathrm{mm}^{-1}\right)$ & 0.259 & 0.941 & 0.253 & 0.927 & 0.272 & 0.977 \\
\hline$\theta$ Range $\left(^{\circ}\right)$ & 3.03 to 27.50 & 3.02 to 25.35 & 3.17 to 25.34 & 3.01 to 25.35 & 3.34 to 27.50 & 3.03 to 26.37 \\
\hline $\begin{array}{l}\text { Reflections } \\
\text { collected }\end{array}$ & 7538 & 34,645 & 12,652 & 12,987 & 10,790 & 13,024 \\
\hline $\begin{array}{l}\text { Independent } \\
\text { reflections }\end{array}$ & 2850 & 4799 & 4678 & 4872 & 2773 & 5220 \\
\hline $\mathrm{R}$ (int) & 0.022 & 0.0687 & 0.0719 & 0.0292 & 0.0514 & 0.0208 \\
\hline Data & 2850 & 4799 & 4678 & 4872 & 2773 & 5220 \\
\hline restraints & 0 & 0 & 2 & 0 & 0 & 17 \\
\hline Parameters & 165 & 344 & 334 & 335 & 163 & 334 \\
\hline GOF on $\mathrm{F}^{2}$ & 1.011 & 1.009 & 1.098 & 1.079 & 0.999 & 1.023 \\
\hline $\mathrm{R} 1[\mathrm{I}>2 \operatorname{sigma}(\mathrm{I})]$ & 0.0436 & 0.0904 & 0.0838 & 0.0536 & 0.0422 & 0.0406 \\
\hline wR2 [I > 2sigma(I)] & 0.1141 & 0.1785 & 0.1771 & 0.1242 & 0.1084 & 0.1002 \\
\hline $\mathrm{R} 1$ [all data] & 0.0551 & 0.11 & 0.1575 & 0.0723 & 0.0636 & 0.0564 \\
\hline wR2 [all data] & 0.1222 & 0.1892 & 0.2080 & 0.1353 & 0.1190 & 0.1105 \\
\hline $\begin{array}{c}\text { Largest difference } \\
\text { peak }\left(\mathrm{e} . \mathrm{A}^{-3}\right)\end{array}$ & $\begin{array}{c}0.362 \text { and } \\
-0.377 \\
\end{array}$ & $\begin{array}{c}0.728 \text { and } \\
-0.413 \\
\end{array}$ & $\begin{array}{c}0.265 \text { and } \\
-0.316 \\
\end{array}$ & $\begin{array}{c}0.627 \text { and } \\
-0.297 \\
\end{array}$ & $\begin{array}{c}0.331 \text { and } \\
-0.449 \\
\end{array}$ & $\begin{array}{c}0.552 \text { and } \\
-0.315 \\
\end{array}$ \\
\hline
\end{tabular}


The crystal structure of $\left[\mathrm{Ni}(\mathrm{L} 2)_{2}\right]$ shows static disorder for the fluorine atoms on one phenyl ring so the positions of atoms cannot be determined with a sufficient accuracy. All of complexes exhibit cis-tetracoordinate structures around nickel(II) in the crystalline molecules, which are similar to those of [Ni(L4) 2] [32], cis-bis(1,1-diethyl-3-benzoylthiourea)-nickel(II) [33] and cis-bis(1,1-diethyl-3-(2chlorobenzoylthiourea-O,S)-nickel(II) [34]. The slightly distorted square geometry is also found in the structure of the three complexes. The $\mathrm{O}-\mathrm{Ni}-\mathrm{O}, \mathrm{S}-\mathrm{Ni}-\mathrm{S}$ and $\mathrm{O}-\mathrm{Ni}-\mathrm{S}$ angles deviate slightly from $90.0^{\circ}$. The conformation isomerizes, which must have happened during the coordination process. The C1-N1-C8-S1 and C14-N3-C21-S2 torsion angles (Table 2) corresponding to the cis-conformation are completely different from the trans-conformations of the ligands.

Table 2. Some structure parameters of the determined crystals

\begin{tabular}{ccccccc}
\hline Distances $(\AA)$ & HL2 & {$\left[\mathbf{N i}(\mathbf{L 2})_{2}\right]$} & HL3 & {$\left[\mathbf{N i ( L 3 ) _ { 2 } ]}\right.$} & HL6 & $\left.[\mathbf{N i ( L 6 )})_{2}\right]$ \\
\hline $\mathrm{Ni}(1)-\mathrm{O}(1)$ & & $1.859(4)$ & & $1.864(2)$ & & $1.861(18)$ \\
$\mathrm{Ni}(1)-\mathrm{O}(2)$ & & $1.846(4)$ & & $1.866(2)$ & & $1.864(18)$ \\
$\mathrm{Ni}(1)-\mathrm{S}(1)$ & & $2.130(2)$ & & $2.140(11)$ & & $2.145(8)$ \\
$\mathrm{Ni}(1)-\mathrm{S}(2)$ & & $2.147(2)$ & & $2.139(11)$ & & $2.142(8)$ \\
$\mathrm{S}(1)-\mathrm{C}(8)$ & $1.673(15)$ & $1.728(7)$ & $1.668(5)$ & $1.742(4)$ & $1.679(2)$ & $1.737(2)$ \\
$\mathrm{S}(2)-\mathrm{C}(21)$ & & $1.723(6)$ & $1.666(5)$ & $1.731(4)$ & & \\
$\mathrm{S}(2)-\mathrm{C}(20)$ & & & & & & $1.731(3)$ \\
$\mathrm{O}(1)-\mathrm{C}(1)$ & $1.215(19)$ & $1.271(7)$ & $1.233(5)$ & $1.275(4)$ & $1.219(2)$ & $1.268(3)$ \\
$\mathrm{O}(2)-\mathrm{C}(14)$ & & $1.269(7)$ & $1.233(6)$ & $1.268(4)$ & & \\
$\mathrm{O}(2)-\mathrm{C}(13)$ & & & & & & $1.272(3)$ \\
$\mathrm{N}(1)-\mathrm{C}(1)$ & $1.378(18)$ & $1.319(7)$ & $1.358(6)$ & $1.312(4)$ & $1.392(2)$ & $1.321(3)$ \\
$\mathrm{N}(3)-\mathrm{C}(14)$ & & $1.309(7)$ & $1.358(6)$ & $1.319(5)$ & & \\
$\mathrm{N}(3)-\mathrm{C}(13)$ & & & & & & $1.307(3)$ \\
$\mathrm{N}(1)-\mathrm{C}(8)$ & $1.413(19)$ & $1.337(8)$ & $1.434(6)$ & $1.340(5)$ & $1.397(2)$ & $1.342(3)$ \\
$\mathrm{N}(3)-\mathrm{C}(21)$ & & $1.341(8)$ & $1.430(6)$ & $1.334(5)$ & & \\
\hline
\end{tabular}

The conformational disposition in the complexes must be derived from the electron delocalization along the S1-C8-N1-C1-O1 fragment. The N1-C1, N3-C14, N1-C8 and N3-C21 distances are shorter than the $\mathrm{N} 1-\mathrm{C} 1$ and $\mathrm{N} 1-\mathrm{C} 8$ distances in the ligands. The distances of $\mathrm{N} 2-\mathrm{C} 8$ and $\mathrm{N} 4-\mathrm{C} 21$ in the complexes are longer than the distance of $\mathrm{N} 2-\mathrm{C} 8$ in the ligands. As Table 2 shows, all $\mathrm{N}-\mathrm{C}$ bond distances are between a $\mathrm{C}-\mathrm{N}$ single bond $(1.468 \AA$ ) and double bond $(1.25 \AA)$. The $\mathrm{O}-\mathrm{C}$ and $\mathrm{S}-\mathrm{C}$ bonds in the complexes are longer than those in the ligands.

\subsection{Antifungal Activities}

The average values of the minimum inhibitory concentration (MIC) of the ligands and their complexes against the fungal strains are shown in Table 3. Taking the commercial fluconazole, the ligands $N$-(piperidine-1-thioyl)benzamide (HL1), $N$-(morpholine-4-thioyl)benzamide (HL4) and their complexes, $\left[\mathrm{Ni}(\mathrm{L} 1)_{2}\right]$ and $\left[\mathrm{Ni}(\mathrm{L} 4)_{2}\right]$ as reference, the ligands and the complexes containing fluorine atoms had good performance inhibiting the growth of the fungi. Especially, the antifungal abilities of HL6 are equal to that of commercial fluconazole; the MIC values against the fungi Botrytis cinerea, Trichoderma spp., Myrothecium and Verticillium spp. are 8.0, 8.5, 7.0 and $8.5 \mu \mathrm{mol} / \mathrm{L}$, while those of 
fluconazole are 7.0, 8.0, 7.5 and $7.5 \mu \mathrm{mol} / \mathrm{L}$, respectively. Moreover, four ligands also have the stronger antifungal abilities than the corresponding complexes. For example, the MIC values for $\left[\mathrm{Ni}(\mathrm{L} 6)_{2}\right]$ are 31.0 (Botrytis cinerea), 25.0 (Trichoderma spp.), 27.5 (Myrothecium) and $27.5 \mu \mathrm{mol} / \mathrm{L}$ (Verticillium spp.), respectively, much higher than that of HL6 (mentionedabove). The results are similar to the antibacterial activities [24]. The inhibitory abilities of the piperidinyl ligands are inferior to those of morpholine ligands. The MIC values for HL3 were 20.5 (Botrytis cinerea), 18.0 (Trichoderma spp.), 22.5 (Myrothecium) and $25.0 \mu \mathrm{mol} / \mathrm{L}$ (Verticillium spp.), respectively, which differ from the antibacterial activities [24]. The position effect is more apparent. The introduction of a $\mathrm{F}$ atom at the para-position of the benzoyl increased the antifungal activities notably. Contrarily, when the $\mathrm{F}$ atom substitutes the benzoyl ortho-position, the antifungal abilities decrease.

Table 3. The MIC of the ligands and their complexes against the studied fungi (SD: standard deviation).

\begin{tabular}{ccccc}
\hline Samples & Botrytis cinerea & Trichoderma spp. & Myrothecium & Verticillium. spp. \\
\hline Fluconazoleole & $7.0 \pm 0.1$ & $8.0 \pm 0.1$ & $7.5 \pm 0.1$ & $7.5 \pm 0.1$ \\
$\mathrm{HL} 1$ & $31.0 \pm 0.0$ & $22.5 \pm 0.1$ & $32.5 \pm 0.1$ & $34.0 \pm 0.0$ \\
{$\left[\mathrm{Ni}(\mathrm{L} 1)_{2}\right]$} & $33.0 \pm 0.0$ & $31.5 \pm 0.1$ & $36.0 \pm 0.0$ & $38.0 \pm 0.1$ \\
$\mathrm{HL} 2$ & $27.5 \pm 0.0$ & $29.0 \pm 0.0$ & $27.5 \pm 0.1$ & $28.0 \pm 0.0$ \\
{$\left[\mathrm{Ni}(\mathrm{L} 2)_{2}\right]$} & $31.0 \pm 0.1$ & $33.0 \pm 0.1$ & $31.0 \pm 0.1$ & $31.5 \pm 0.1$ \\
$\mathrm{HL} 3$ & $20.5 \pm 0.1$ & $18.0 \pm 0.1$ & $22.5 \pm 0.1$ & $25.0 \pm 0.0$ \\
{$\left[\mathrm{Ni}(\mathrm{L} 3)_{2}\right]$} & $22.5 \pm 0.0$ & $31.0 \pm 0.0$ & $29.0 \pm 0.1$ & $31.0 \pm 0.0$ \\
$\mathrm{HL} 4$ & $2.5 \pm 0.1$ & $2 \pm 0.0$ & $2.3 \pm 0.0$ & $0.8 \pm 0.1$ \\
{$\left[\mathrm{Ni}(\mathrm{L} 4)_{2}\right]$} & $29.0 \pm 0.1$ & $32.5 \pm 0.1$ & $35.5 \pm 0.1$ & $35.5 \pm 0.1$ \\
$\mathrm{HL} 5$ & $31.0 \pm 0.1$ & $27.5 \pm 0.0$ & $27.5 \pm 0.0$ & $31.0 \pm 0.1$ \\
{$\left[\mathrm{Ni}(\mathrm{L} 5)_{2}\right]$} & $32.5 \pm 0.1$ & $31.0 \pm 0.1$ & $31.0 \pm 0.1$ & $31.5 \pm 0.0$ \\
$\mathrm{HL} 6$ & $8.0 \pm 0.0$ & $8.5 \pm 0.0$ & $7.0 \pm 0.1$ & $8.5 \pm 0.0$ \\
{$\left[\mathrm{Ni}(\mathrm{L} 6)_{2}\right]$} & $31.0 \pm 0.0$ & $25.0 \pm 0.0$ & $27.5 \pm 0.1$ & $27.5 \pm 0.0$ \\
\hline
\end{tabular}

\subsection{Structure-Activity Relationships}

On the one hand, organic molecules containing $\mathrm{F}$ have the good lipophilicity and thus enhanced rates of cell penetration and transport to an active site [23]. Furthermore, the fluorination adjacent to a $\pi$-system or heteroatom-containing functional group can strongly polarize the parent molecule [35]. Taking morpholine and piperidine as the donors and $\mathrm{F}$ atoms as the acceptors, the ligands containing $\mathrm{F}$ would form a D-A molecular system. The D-A model molecules will be more active in the interaction with biomolecules than the common, so the molecules should have strong antimicrobial activity.

The change of the antimicrobial activity is mostly attributed to the change of the structures in the ligands and the complexes. The change in the structures must result in the change of the charge population on the atoms of the complexes and accordingly induce the differences of antimicrobial activities. In our recent work, it was found that the lower the LUMO energy was, the more polar the C-N of the acyl was, and the higher the antibacterial activity was [29]. In the crystal structures of HL2, HL3 and HL6, the average $\mathrm{C}-\mathrm{N}$ bond of the acyl measures 1.374, 1.368 and $1.392 \AA$, respectively. HL6 has the longest $\mathrm{C}-\mathrm{N}$ bond, so the $\mathrm{C}-\mathrm{N}$ polarity is the largest and the antimicrobial activity must be the strongest. Upon coordination, the $\mathrm{C}-\mathrm{O}$ and $\mathrm{C}-\mathrm{S}$ bonds weaken and the amide $\mathrm{C}-\mathrm{N}$ bonds gradually strengthen. The average $\mathrm{C}-\mathrm{N}$ bond distances of $1.319(7), 1.312(4)$ and $1.321(3) \AA$ in $\left[\mathrm{Ni}(\mathrm{L} 2)_{2}\right]$, 
$\left[\mathrm{Ni}(\mathrm{L} 3)_{2}\right]$ and $\left[\mathrm{Ni}(\mathrm{L} 6)_{2}\right]$ are shorter than those of the $\mathrm{C}-\mathrm{N}$ bond of the amide, 1.378(18), 1.358(6) and 1.392(2) $\AA$ in the corresponding free ligands, HL2, HL3 and HL6. The shortened bond length of the amide $\mathrm{C}-\mathrm{N}$ bond is a disadvantage for the polarity increase, so the antifungal activity of the complexes will decrease.

For HL2, the intramolecular hydrogen bonding $\mathrm{N}-\mathrm{H} \cdots \mathrm{F}$ will decrease the polarity of the molecules, and is also disadvantage for the polarity increase of the $\mathrm{C}-\mathrm{N}$ bond of the amide. For HL3, no intramolecular hydrogen bonding interactions exist, but, a dimer is formed in the crystals of HL 3 due to the strong intermolecular $\mathrm{N}-\mathrm{H} \cdots \mathrm{O}$ hydrogen bonding interactions, with a $\mathrm{H} \cdots \mathrm{O}$ distance of $2.118, \mathrm{~N} \cdots \mathrm{O}$ distance of $2.965 \AA$, and $\angle \mathrm{N}-\mathrm{H} \cdots \mathrm{O}$ of $173.8^{\circ}$. This hydrogen bonding results in a longer $\mathrm{C}-\mathrm{O}$ bond $(1.233 \AA$ Á), which disturbs the polarity of amide $\mathrm{C}-\mathrm{N}$ bond. In the crystal structure of HL6, because the $\mathrm{O}$ atom of morpholine replaces the carbon atom of piperidine, two weak intermolecular $\mathrm{N}-\mathrm{H} \cdots \mathrm{O}(1)$ interactions with $\mathrm{H} \cdots \mathrm{O}$ distances of 2.423 and $2.922, \mathrm{~N} \cdots \mathrm{O}$ distances of 3.408 and $3.104 \AA$, and $\angle \mathrm{N}-\mathrm{H} \cdots \mathrm{O}, 125.3^{\circ}$ and $135.4^{\circ}$ are observed instead of the strong $\mathrm{N}-\mathrm{H} \cdots \mathrm{O}$ intermolecular hydrogen bonding interactions in HL3 (Figure 4). The weak interactions do not affect the polarity of the amide $\mathrm{C}-\mathrm{N}$ bond, so HL6 has the strongest antifungal activity.

Figure 4. The packing diagrams of the corresponding hydrogen bonds of ligands.

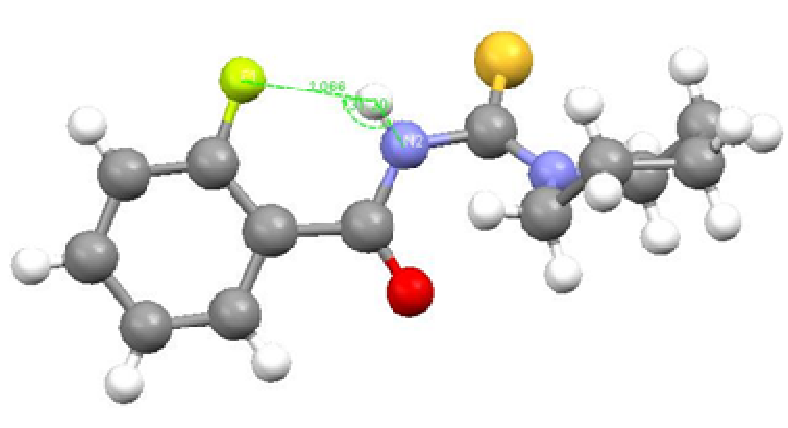

HL2

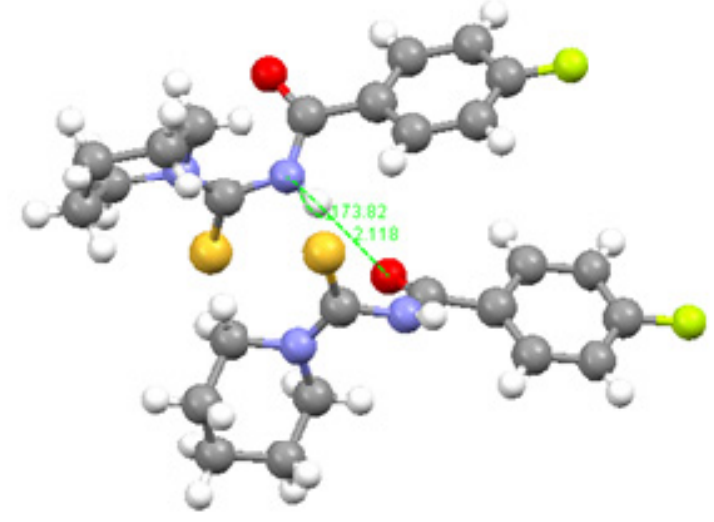

HL3

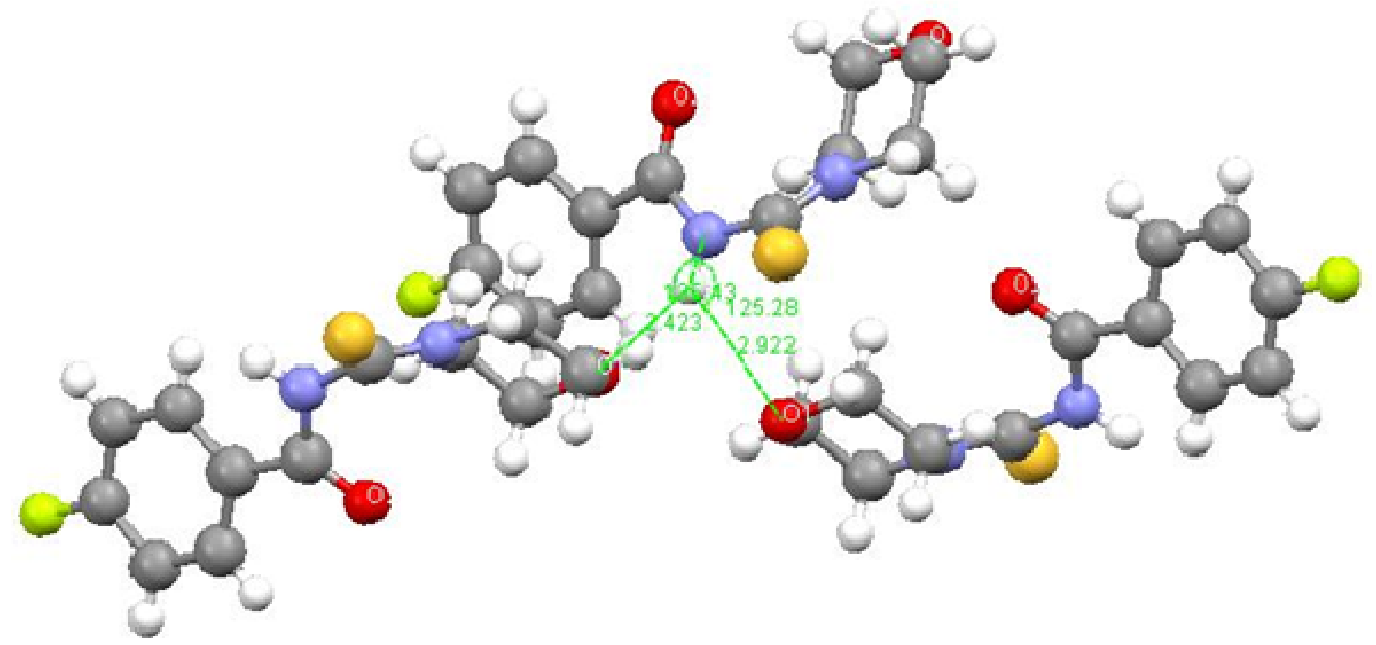

HL6 


\section{Experimental}

\subsection{Materials}

Melting points were measured with Kofler melting point apparatus (Tallmadge, OH, USA) and were uncorrected. IR spectra were obtained in $\mathrm{KBr}$ discs using a Nicolet 170SX FT-IR spectrometer (Thermo Fisher Scientific, Shanghai, China). ${ }^{1} \mathrm{H}-\mathrm{NMR}$ (400.13 MHz) spectra were recorded in chloroform-d $\left(\mathrm{CDCl}_{3}\right)$ solution at room temperature on an INOVA 400 instrument (VARIAN, Palo Alto, CA, USA) with TMS as internal reference. Elemental analyses were performed on a Yanaco CHNSO Corder MT-3 analyzer (PerkinElmer, Waltham, MA, USA). X-ray diffraction determination was carried out with a Rigaku Mercury CCD diffractometer (Rigaku, Japan).

\subsection{Synthesis}

The synthetic route to the target ligands given in the literature [28] was used, as outlined in Scheme 1. Fluorobenzoyl chlorides were obtained by the acylation reaction of the corresponding fluorobenzoic acids with thionyl chloride.

Scheme 1. Synthetic route of the ligands and the complexes.

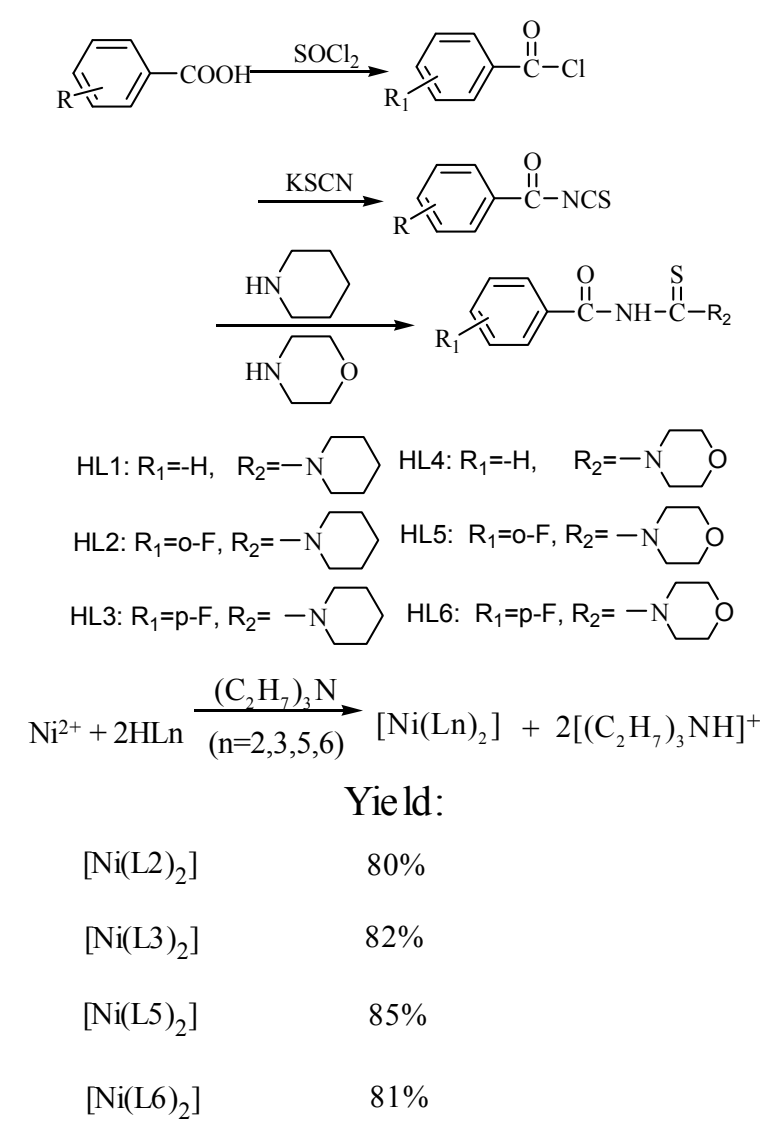

Then, a freshly prepared acetone solution of benzoyl isothiocyanate synthesized by the condensation of fluorobenzoyl chloride with KSCN was added dropwise to a stoichiometric amount of morpholine or piperidine solution with stirring. The mixture was heated and refluxed for $1-2 \mathrm{~h}$. After that, the mixture was poured on crushed ice with vigorous stirring. The isolated solids was filtered, 
washed with water and dried to yield the target ligands. The synthees of the complexes are also depicted in Scheme 1. The complexes were obtained by the reaction of anhydrous $\mathrm{NiSO}_{4}$ with the corresponding ligands (molar ratio of $\mathrm{Ni}^{2+}: \mathrm{L}=1: 2$ ) in ethanol in the presence of triethylamine. All of ligands and complexes are air-stable enough to be used for the antimicrobial property studies.

[Ni(L2) 2 ]: Dark green solid, m.p.:186.5-188.4 ${ }^{\circ} \mathrm{C}$. Anal. Calc. for $\mathrm{C}_{26} \mathrm{H}_{28} \mathrm{~F}_{2} \mathrm{~N}_{4} \mathrm{NiO}_{2} \mathrm{~S}_{2}(\% \mathrm{C}, \mathrm{H}, \mathrm{N}$ and S): 52.97, 4.75, 9.51 and 10.87. Found (\% C, H, N and S): 52.92, 4.81, 9.46 and 10.92. FTIR $\left(\mathrm{cm}^{-1}\right)$ : $3016\left(\mathrm{w}, \mathrm{v}_{\mathrm{Ph}-\mathrm{H}}\right), 2938\left(\mathrm{w}, \mathrm{v}_{\mathrm{CH} 2}\right), 2857\left(\mathrm{w}, \mathrm{v}_{\mathrm{CH} 2}\right), 1585\left(\mathrm{w}, \mathrm{v}_{\mathrm{Ph}-\mathrm{H}}\right), 1526\left(\mathrm{~m}, \mathrm{v}_{\mathrm{Ph}-\mathrm{H}}\right), 1489$ (m, $\left.\mathrm{v}_{\mathrm{Ph}-\mathrm{H}}\right), 1414$ $\left(\mathrm{m}, \delta_{\mathrm{CH} 2}\right), 1358\left(\mathrm{w}, \mathrm{v}_{\mathrm{C}-\mathrm{F}}\right), 1244\left(\mathrm{w}, \mathrm{v}_{\mathrm{C}-\mathrm{O}}\right), 1132\left(\mathrm{w}, \mathrm{v}_{\mathrm{C}-\mathrm{N}}\right), 1020\left(\mathrm{w}, \mathrm{v}_{\mathrm{C}-\mathrm{S}}\right), 758\left(\mathrm{w}, \delta_{\mathrm{Ph}-\mathrm{H}}\right) .{ }^{1} \mathrm{H}-\mathrm{NMR}$ (ppm): 7.96-7.93 (t, 2H, $J=6.8,6.4 \mathrm{~Hz}), 7.38(\mathrm{~s}, 2 \mathrm{H}), 7.14-7.10$ (t, 2H, $J=7.2,7.2 \mathrm{~Hz}), 7.05-7.00$ (t, 2H, $J=9.6,9.2 \mathrm{~Hz}), 4.06(\mathrm{~s}, 2 \mathrm{H}), 3.96(\mathrm{~s}, 2 \mathrm{H}), 3.96(\mathrm{~s}, 4 \mathrm{H}), 1.68-1.61(\mathrm{~d}, 12 \mathrm{H}, J=28.8 \mathrm{~Hz})$.

[Ni(L3) 2 ]: Dark green solid, m.p.: 238.9-240.6 ${ }^{\circ} \mathrm{C}$. Anal. Calc. for $\mathrm{C}_{26} \mathrm{H}_{28} \mathrm{~F}_{2} \mathrm{~N}_{4} \mathrm{NiO}_{2} \mathrm{~S}_{2}(\% \mathrm{C}, \mathrm{H}, \mathrm{N}$ and S): 52.97, 4.75, 9.51 and 10.87. Found (\% C, H, N and S): 52.95, 4.80, 9.54 and 10.80. FTIR $\left(\mathrm{cm}^{-1}\right)$ : $3030\left(\mathrm{w}, v_{\mathrm{Ph}-\mathrm{H}}\right), 2941\left(\mathrm{w}, v_{\mathrm{CH} 2}\right), 2860\left(\mathrm{w}, v_{\mathrm{CH} 2}\right), 1601\left(\mathrm{w}, v_{\mathrm{Ph}-\mathrm{H}}\right), 1518\left(\mathrm{~m}, v_{\mathrm{Ph}-\mathrm{H}}\right), 1483\left(\mathrm{~m}, v_{\mathrm{Ph}-\mathrm{H}}\right), 1424$ $\left(\mathrm{m}, \delta_{\mathrm{CH} 2}\right), 1364\left(\mathrm{w}, \mathrm{v}_{\mathrm{C}-\mathrm{F}}\right), 1244\left(\mathrm{w}, \mathrm{v}_{\mathrm{C}-\mathrm{O}}\right), 1150\left(\mathrm{w}, \mathrm{v}_{\mathrm{C}-\mathrm{N}}\right), 1018\left(\mathrm{w}, \mathrm{v}_{\mathrm{C}-\mathrm{S}}\right), 856\left(\mathrm{w}, \delta_{\mathrm{Ph}-\mathrm{H}}\right) .{ }^{1} \mathrm{H}-\mathrm{NMR}(\mathrm{ppm})$ : $8.10(\mathrm{~s}, 4 \mathrm{H}), 7.05(\mathrm{~s}, 4 \mathrm{H}), 4.08-3.98(\mathrm{~d}, 8 \mathrm{H}, J=24 \mathrm{~Hz}), 1.69(\mathrm{~s}, 12 \mathrm{H})$.

[Ni(L5) $)_{2}$ : Brown solid, m.p.: 229.6-230.0 ${ }^{\circ} \mathrm{C}$. Anal. Calc. for $\mathrm{C}_{24} \mathrm{H}_{24} \mathrm{~F}_{2} \mathrm{~N}_{4} \mathrm{NiO}_{4} \mathrm{~S}_{2}(\% \mathrm{C}, \mathrm{H}, \mathrm{N}$ and S): 48.57, 4.05, 9.44 and 10.79. Found (\% C, H, N and S): 47.90, 4.10, 9.42 and 10.68. FTIR (cm $\left.{ }^{-1}\right): 3076$ $\left(\mathrm{w}, v_{\mathrm{Ph}-\mathrm{H}}\right), 2923\left(\mathrm{w}, v_{\mathrm{CH} 2}\right), 2856\left(\mathrm{w}, v_{\mathrm{CH} 2}\right), 1589\left(\mathrm{w}, v_{\mathrm{Ph}-\mathrm{H}}\right), 1521\left(\mathrm{~m}, v_{\mathrm{Ph}-\mathrm{H}}\right), 1473\left(\mathrm{~m}, v_{\mathrm{Ph}-\mathrm{H}}\right), 1419(\mathrm{w}$, $\left.\delta_{\mathrm{CH} 2}\right), 1356\left(\mathrm{w}, \mathrm{v}_{\mathrm{C}-\mathrm{F}}\right), 1252\left(\mathrm{w}, \mathrm{v}_{\mathrm{C}-\mathrm{O}}\right), 1110\left(\mathrm{w}, \mathrm{v}_{\mathrm{C}-\mathrm{N}}\right), 1020\left(\mathrm{w}, \mathrm{v}_{\mathrm{C}-\mathrm{S}}\right), 755\left(\mathrm{w}, \delta_{\mathrm{Ph}-\mathrm{H}}\right) .{ }^{1} \mathrm{H}-\mathrm{NMR}(\mathrm{ppm}): 7.97$ $(\mathrm{d}, 2 \mathrm{H}, J=0.8 \mathrm{~Hz}), 7.44(\mathrm{~d}, 1 \mathrm{H}, J=2.0 \mathrm{~Hz}), 7.18-7.15$ (t, 2H, $J=6.0,7.2 \mathrm{~Hz}), 7.09-7.05$ (t, 2H, $J=8.8,8.4 \mathrm{~Hz}), 4.18-4.05(\mathrm{~d}, 6 \mathrm{H}, J=24 \mathrm{~Hz}), 3.78-3.74(\mathrm{~d}, 6 \mathrm{H}, J=16.4 \mathrm{~Hz}), 2.99-2.91(\mathrm{~d}, 2 \mathrm{H}$, $J=29.6 \mathrm{~Hz}), 1.61(\mathrm{~s}, 2 \mathrm{H})$.

[Ni(L6) 2 ]: Pink solid, m.p.: 302.9-303.1 ${ }^{\circ} \mathrm{C}$. Anal. Calc. for $\mathrm{C}_{24} \mathrm{H}_{24} \mathrm{~F}_{2} \mathrm{~N}_{4} \mathrm{NiO}_{4} \mathrm{~S}_{2}(\% \mathrm{C}, \mathrm{H}, \mathrm{N}$ and S): 48.57, 4.05, 9.44 and 10.79. Found (\% C, H, N and S): 48.63, 3.99, 9.42 and 10.82. FTIR $\left(\mathrm{cm}^{-1}\right): 3046$ $\left(\mathrm{w}, v_{\mathrm{Ph}-\mathrm{H}}\right), 2968\left(\mathrm{w}, v_{\mathrm{CH} 2}\right), 2856\left(\mathrm{w}, v_{\mathrm{CH} 2}\right), 1601\left(\mathrm{w}, v_{\mathrm{Ph}-\mathrm{H}}\right), 1515\left(\mathrm{~m}, v_{\mathrm{Ph}-\mathrm{H}}\right), 1474\left(\mathrm{~m}, v_{\mathrm{Ph}-\mathrm{H}}\right), 1419(\mathrm{~m}$, $\left.\delta_{\mathrm{CH} 2}\right), 1350\left(\mathrm{w}, v_{\mathrm{C}-\mathrm{F}}\right), 1260\left(\mathrm{w}, \mathrm{v}_{\mathrm{C}-\mathrm{O}}\right), 1150\left(\mathrm{w}, \mathrm{v}_{\mathrm{C}-\mathrm{N}}\right), 1028\left(\mathrm{w}, \mathrm{v}_{\mathrm{C}-\mathrm{S}}\right), 852\left(\mathrm{w}, \delta_{\mathrm{Ph}-\mathrm{H}}\right) .{ }^{1} \mathrm{H} \mathrm{NMR}\left(\mathrm{CDCl}_{3}\right)$ (ppm): 8.21 (s, 4H), 7.08-7.41 (t, 4H, $J=8.4,8.4 \mathrm{~Hz}), 4.17-4.16$ (d, 4H, $J=4.4 \mathrm{~Hz}), 4.05-4.04$ $(\mathrm{d}, 4 \mathrm{H}, J=4.4 \mathrm{~Hz}), 3.77-3.76(\mathrm{~d}, 4 \mathrm{H}, J=4.4 \mathrm{~Hz}), 2.18(\mathrm{~s}, 2 \mathrm{H}), 1.62(\mathrm{~s}, 2 \mathrm{H})$.

\subsection{X-ray Structure Determination}

Crystals suitable for the X-ray diffraction determination were prepared by solvent evaporation method in dimethylformamide (DMF). All measurements were operated on a Rigaku Mercury CCD $\mathrm{X}$-ray diffractometer [36] by using graphite monochromated MoK $\alpha$ radiation $(\lambda=0.71070 \AA)$. Single crystals were mounted with grease at the top of a glass fiber. Cell parameters were refined on all observed reflections by using the program CrystalClear (Rigaku and MSC, Ver. 1.3, 2001) [37]. The collected data were reduced by the program CrystalClear and an absorption correction (multiscan) was applied.

The reflection data of the crystals were corrected by Lorentz and polarization effects. The crystal structures were solved by direct methods and refined by full-matrix least-squares methods $\left(\mathrm{F}^{2}\right)$ using the 
SHELXTL software package [38,39]. Non-hydrogen atoms were refined anisotropically and hydrogen atoms were placed at calculated positions. The structure of $\left[\mathrm{Ni}(\mathrm{L} 2)_{2}\right]$, involved one orientation disorder, and the molecule was refined in two positions, the main position of the atom F1A was $56.8 \%$ and the secondary position of the atom F1B was $43.2 \%$. The summary of the key crystallographic information and the selected bond lengths and bond angles for both crystals was listed in Tables 2-3 respectively. The other information of the crystals had been deposited in the Cambridge Crystallographic Data Centre as CCDC 836,547 (HL2), CCDC 845,010 (HL3), CCDC 877,566 (HL6), 875, 172 ([Ni(L2)2]), 878,379 $\left(\left[\mathrm{Ni}(\mathrm{L} 3)_{2}\right]\right)$ and 882,281 ([Ni (L6) 2$\left.]\right)$. These data can be obtained free of charge from The Cambridge Crystallographic Data Centre via www.ccdc.cam.ac.uk/data_request/cif.

\subsection{Determination of the Minimum Inhibitory Concentration (MIC)}

The MIC of the test samples was determined by a two-fold serial dilution method. We pre-cultured the studied fungi for $24 \mathrm{~h}$ at $28{ }^{\circ} \mathrm{C}$ in LB (Luria-Bertani) liquid medium (tryptone $10 \mathrm{~g}$, yeast extract $5 \mathrm{~g}, \mathrm{NaCl} 10 \mathrm{~g}$ and $500 \mathrm{~mL}$ of distilled water). Then, taking the same concentration of the studied fungi cultured for $24 \mathrm{~h}$ in LB liquid medium. Subsequently, the different concentrations of the test samples were added into the LB liquid medium containing the studied fungi and cultured for $24 \mathrm{~h}$ at $28{ }^{\circ} \mathrm{C}$ (dimethyl sulfoxide (DMSO) as the control and fluconazole as the reference). The culture solution $(50 \mu \mathrm{L})$ was inoculated on the LB solid medium to observe the growth of the colony and the MIC was the highest dilution concentration of no growth of the fungi. Each concentration repeated three times for each fungus. Differences between the experimental group and the control group were analyzed by Least Significant Difference (LSD) t-test. $p<0.05$ was considered to indicate a statistically significant difference. In this work, all results of experiments were measured up to $p<0.05$.

\section{Conclusions}

Four fluorine-containing thiourea complexes ([Ni(L2) 2$\left.],\left[\mathrm{Ni}(\mathrm{L} 3)_{2}\right],\left[\mathrm{Ni}(\mathrm{L} 5)_{2}\right],\left[\mathrm{Ni}(\mathrm{L} 6)_{2}\right]\right)$ have been successfully synthesized. The crystal structures of HL2, HL3, HL6 and the nickel complexes have been determined by X-ray diffraction. The $\left[\mathrm{Ni}(\mathrm{L} 2)_{2}\right],\left[\mathrm{Ni}(\mathrm{L} 3)_{2}\right]$ and $\left[\mathrm{Ni}(\mathrm{L} 6)_{2}\right]$ complexes have similar cis-tetracoordinate structures.

The antifungal activity assays show the introducing fluorine in the para-position of the benzoyl moiety in ligands is a very powerful and versatile tool to increase antifungal activities by changing the electronic parameters and forming a D-A system. The presence of intra- and intermolecular hydrogen bonding interactions and the coordination will be disadvantage for increasing the polarity of the amide $\mathrm{C}-\mathrm{N}$ bond and this decreases the antifungal activities, so the antifungal activity of HL6 is the strongest among the studied samples, and is the same as that of the commercial fungicide fluconazole.

\section{Acknowledgments}

This work was supported by the National Natural Science Foundation of China (No. 51079094) and the Natural Science Foundation of Jiangsu Province (No. BK2010215). 


\section{Conflicts of Interest}

The authors declare no conflict of interest.

\section{References}

1. Krogul, A.; Cedrowski, J.; Wiktorska, K.; Oziminski, W.P.; Skupińska, J.; Litwinienko, G. Biological activity of $\mathrm{Pd}(\mathrm{II})$ complexes with mono- and disubstituted pyridines-Experimental and theoretical studies. Bioorg. Med. Chem. Lett. 2013, 23, 2765-2768.

2. Kim, B.Y.; Ahn, J.B.; Lee, H.W.; Kang, S.K.; Lee, J.H.; Shin, J.S.; Ahn, S.K.; Hong, C.; Yoon, S.S. Synthesis and biological activity of novel substituted pyridines and purines containing 2,4-thiazolidinedione. Eur. J. Med. Chem. 2004, 39, 433-447.

3. Çolak, A.T.; Çolak, F.; Akduman, D.; Yeşilel, O.Z.; Büyükgüngör, O. Syntheses, crystal structures, spectral and thermal analysis and biological activities of copper(II)-pyridine-2,5-dicarboxylate complexes with 4-methylimidazole, imidazole, and 3,4-dimethylpyridine. Solid State Sci. 2009, 11, 1908-1918.

4. Yancheva, D.; Daskalova, L.; Cherneva, E.; Mikhova, B.; Djordjevic, A.; Smelcerovic, Z.; Smelcerovic, A. Synthesis, structure and antimicrobial activity of 6-(propan-2-yl)-3-methylmorpholine-2,5-dione. J. Mol. Struct. 2012, 1016, 147-154.

5. Kravchenko, D.V.; Kysil, V.M.; Tkachenko, S.E.; Maliarchouk, S.; Okun, I.M.; Ivachtchenko, A.V. Pyrrolo[3,4-c]quinoline-1,3-diones as potent caspase-3 inhibitors. Synthesis and SAR of 2-substituted 4-methyl-8-(morpholine-4-sulfonyl)-pyrrolo [3,4-c]quinoline-1,3-diones. Eur. J. Med. Chem. 2005, 40, 1377-1383.

6. Patel, N.B.; Purohit, A.C.; Rajani, D.P.; Moo-Puc, R.; Rivera, G. New 2-benzylsulfanyl-nicotinic acid based 1,3,4-oxadiazoles: Their synthesis and biological evaluation. Eur. J. Med. Chem. 2013, 62, 677-687.

7. Venkatachalam, T.K.; Sudbeck, E.A.; Uckun, F.M. Regiospecific synthesis, X-ray crystal structure and biological activities of 5-bromothiophenethyl thioureas. Tetrahedron Lett. 2001, 42, 6629-6632.

8. Yao, J.W.; Chen, J.; He, Z.P.; Sun, W.; Xu, W.F. Design, synthesis and biological activities of thiourea containing sorafenibanalogs as antitumor agents. Bioorg. Med. Chem. 2012, 20, 2923-2929.

9. Saeed, S.; Rashid, N.; Jones, P.G.; Ali, M.; Hussain, R. Synthesis, spectroscopic characterization, crystal structure and pharmacological properties of some novel thiophene-thiourea core derivatives. Eur. J. Chem. 2010, 45, 1323-1331.

10. Ventosa-Andrés, P.; Valdivielso, Á.M.; Pappos, I.; García-López, M.T.; Tsopanoglou, N.E.; Herranz, R. Design, synthesis and biological evaluation of new peptide-based ureas and thioureas as potential antagonists of the thrombin receptor PAR1. Eur. J. Med. Chem. 2012, 58, 98-111.

11. Mohamed, M.S.; Kamel, M.M.; Kassem, E.M.M.; Abotaleb, N.; Abd El-moez, S.I.; Ahmed, M.F. Novel 6,8-dibromo-4(3H)quinazolinone derivatives of anti-bacterial and anti-fungal activities. Eur. J. Med. Chem. 2010, 45, 3311-3319.

12. Zhou, W.Q.; Yang, W.; Xie, L.Q.; Cheng, X.C. $N$-Benzoyl- $N$ '-dialkylthiourea derivatives and their Co(III) complexes: Structure, and antifungal. J. Inorg. Biochem. 2005, 99, 1314-1319. 
13. Upadlgaya, J.S.; Srivastava, P.K. Potential antithyroid agents. Part V: Synthetic and pharmacological studies on some $N$-aryl- $N$ '-benzoylthiocarbamides. J. Ind. Chem. Soc. 1982, 59, 767-769.

14. Emen, M.F.; Arslan, H.; Kulcu, N.; Florke, U.; Duran, N. Synthesis, characterization and antimicrobial activities of some metal complexes with $N^{\prime}$-(2-chloro-benzoyl)thiourea ligands: The crystal structure of fac-[CoL3] and cis-[PdL2]. Pol. J. Chem. 2005, 79, 1615-1626.

15. Smart, B.E. Fluorine substituent effects (on bioactivity). J. Fluorine Chem. 2001, 109, 3-11.

16. Bonacorso, H.G.; Wentz, A.P.; Lourega, R.V.; Cechinel, C.A.; Moraes, T.S.; Coelho, H.S.; Zanatta, N.; Martins, M.A.P.; Hoerner, M.; Alves, S.H. Trifluoromethyl-containing pyrazolinyl ( $p$-tolyl) sulfones: The synthesis and structure of promising antimicrobial agents. J. Fluorine Chem. 2006, 127, 1066-1072.

17. Jagodzinska, M.; Huguenot, F.; Candiani, G.; Zanda, M. Assessing the bioisosterism of the trifluoromethyl group with a protease probe. Chem. Med. Chem. 2009, 4, 49-51.

18. Filler, R.; Saha, R. Fluorine in medicinal chemistry: A century of progress and a 60-year retrospective of selected highlights. Future Med. Chem. 2009, 1, 777-791.

19. Ismail, F.M.D. Important fluorinated drugs in experimental and clinical use. J. Fluorine Chem. 2002, 118, 27-33.

20. Yonetoku, Y.; Kubota, H.; Okamoto, Y.; Ishikawa, J.; Takeuchi, M.; Ohta, M.; Tsukamoto, S. Novel potent and selective calcium-release-activated calcium (CRAC) channel inhibitors. Part 2: Synthesis and inhibitory activity of aryl-3-trifluoromethylpyrazoles. Bioorg. Med. Chem. 2006, 14, 5370-5383.

21. Szymanski, P.; Karpinski, A.; Mikiciuk-Olasik, E. Synthesis, biological activity and HPLC validation of 1,2,3,4-tetrahydroacridine derivatives as acetylcholinesterase inhibitors. Eur. J. Med. Chem. 2011, 46, 3250-3257.

22. Saeed, A.; Shaheen, U.; Hameed, A.; Haider Naqvi, S.Z. Synthesis, characterization and antimicrobial activity of some new 1-(fluorobenzoyl)-3-(fluorophenyl)thioureas. J. Fluorine Chem. 2009, 130, 1028-1034.

23. Mendes, I.C.; Moreira, J.P.; Spez iali, N.L.; Mangrich, A.S.; Takahashi, J.A.; Beraldo, H. $N(4)$-tolyl-2-benzoylpyridine thiosemicarbazones and their copper(II) complexes with significant antifungal activity: Crystal structure of N(4)-para-tolyl-2-benzoylpyridine thiosemicarbazone. Braz. J. Chem. Soc. 2006, 17, 1571-1577.

24. Mendes, I.C.; Soares, M.A.; dos Santos, R.G.; Pinheiro, C.; Beraldo, H. Gallium(III) complexes of 2-pyridineformamide thiosemicarbazones: Cytotoxic activity against malignant glioblastoma. Eur. J. Med. Chem. 2009, 44, 1870-1877.

25. Da Silva, J.G.; Azzolini, L.S.; Wardell, S.M.S.V.; Wardell, J.L.; Beraldo, H. Increasing the antibacterial activity of gallium(III) against Pseudomonas aeruginosa upon coordination to pyridine-derived thiosemicarbazones. Polyhedron 2009, 28, 2301-2305.

26. Mendes, I.C.; Moreira, J.P.; Ardisson, J.D.; dos Santos, R.G.; da Silva, P.R.O.; Garcia, I.; Castiñeiras, A.; Beraldo, H. Organotin(IV) complexes of 2-pyridineformamide-derived thiosemicarbazones: Antimicrobial and cytotoxic effects. Eur. J. Med. Chem. 2008, 43, 1454-1461.

27. Reis, D.C.; Pinto, M.C.X.; Souza-Fagundes, E.M.; Wardell, S.M.S.V.; Wardell, J.L.; Beraldo, H. 2-Acetylpyridine thiosemicarbazones: Cytotoxic activity in nanomolar doses against malignant gliomas. Eur. J. Med. Chem. 2010, 45, 3904-3910. 
28. Bagihalli, G.B.; Avaji, P.G.; Patil, S.A.; Badami, P.S. Synthesis, spectral characterization, in vitro antibacterial, antifungal and cytotoxic activities of $\mathrm{Co}(\mathrm{II}), \mathrm{Ni}(\mathrm{II})$ and $\mathrm{Cu}(\mathrm{II})$ complexes with 1,2,4-triazole Schiff bases. Eur. J. Med. Chem. 2008, 43, 2639-2649.

29. Yang, W.; Liu, H.H.; Li, M.Y.; Wang, F.; Zhou, W.Q.; Fan, J.F. Synthesis, structures and antibacterial activities of benzoylthiourea derivatives and their complexes with cobalt. J. Inorg. Biochem. 2012, 116, 97-105.

30. Alomar, K.; Gaumet, V.; Allain, M.; Bouet, G.; Landreau, A. Synthesis, crystal structure, characterisation, and antifungal activity of 3-thiophene aldehyde semicarbazone (3STCH), 2,3-thiophene dicarboxaldehyde bis(semicarbazone) $\left(2,3 \mathrm{BSTCH}_{2}\right)$ and their nickel (II) complexes. J. Inorg. Biochem. 2012, 115, 36-43.

31. Alves, L.C.; Rubinger, M.M.M.; Lindemann, R.H.; Perpétuo, G.J.; Janczak, J.; Miranda, L.D.L.; Zambolim, L.; Oliveira, M.R.L. Syntheses, crystal structure, spectroscopic characterization and antifungal activity of new $\mathrm{N}$-R-sulfonyldithiocarbimate metal complexes. J. Inorg. Biochem. 2009, 103, 1045-1053.

32. Zhou, W.Q.; Zhu, L.M.; Yong, Z.G.; Yu, Z.F.; Lu, L.; Yang, X.J. Structure and vibrational spectra of the thiourea derivative and its complex with Ni(II). Vib. Spectrosc. 2004, 36, 73-78.

33. Hernández, W.; Spodine, E.; Richter, R.; Griebel, J.; Kirmsec, R.; Schröder, U.; Beyer, L. Cis-trans isomerism in Copper(II) complexes with $N$-acyl thiourea ligands. Z. Anorg. Allg. Chem. 2004, 630, 1381-1386.

34. Abdelhady, A.L.; Ramasamy, K.; Malik, M.A.; O’Brien, P.; Haigh, S.J.; Raftery, J. New routes to copper sulfide nanostructures and thin films. J. Mater. Chem. 2011, 21, 17888-17895.

35. Banks, R.E.; Smart, B.E.; Tatlow, J.C. Organofluorine Chemistry, Principles and Commercial Applications; Plenum Press: New York, NY, USA, 1994; pp. 57-88.

36. Sheldrick, G.M. SHELXS97 and SHELXL97. University of Göttingen: Göttingen, Germany, 1997.

37. Sheldrick, G.M. SHELXTL, Version 5.1; Bruker AXS Inc.: Madison, WI, USA, 1998.

38. CrystalStructure 3.7.0, Single Crystal Structure Analysis Software; Rigaku, Inc.: The Woodlands, TX, USA, 2005-2007.

39. Sheldrick, G.M. CRYSTRCLEAR, Program for Empirical Absorption Correction of Area Detector Data; University of Göttingen: Göttingen, Germany, 2003.

Sample Availability: Samples of the HL2, HL3, HL6, [Ni(L2) $\left.)_{2}\right],\left[\mathrm{Ni}(\mathrm{L} 3)_{2}\right]$ and $\left[\mathrm{Ni}(\mathrm{L} 6)_{2}\right]$ are available from the authors.

(C) 2013 by the authors; licensee MDPI, Basel, Switzerland. This article is an open access article distributed under the terms and conditions of the Creative Commons Attribution license (http://creativecommons.org/licenses/by/3.0/). 